\title{
ZASTOSOWANIE GIER DECYZYJNYCH W ROZWOJU ZASOBÓW LUDZKICH
}

Z a r y s t r e ś c i: Artykuł opisuje wynik eksperymentu polegającego na przeprowadzeniu sesji gry szkoleniowej dla specjalistów ds. zarządzania zasobami ludzkimi w jednym z dużych przedsiębiorstw zlokalizowanych w Polsce północnej. Celem badania było poznanie opinii osób kompetentnych w obszarze rozwoju pracowników na temat gier decyzyjnych oraz zaobserwowanie ich zachowań w sytuacji uczestnictwa w sesji takiej gry.

Słowa kluczowe: gra decyzyjna; rozwój; szkolenie.

K la s y fik a c j a J E L: J24.

\section{WSTĘP}

Celem badania opisanego w niniejszym opracowaniu było zbadanie percepcji gier decyzyjnych przez specjalistów ds. zarządzania zasobami ludzkimi. Zostało ono przeprowadzone z zastosowaniem metody eksperymentu. Polegał on na zorganizowaniu sesji gry decyzyjnej dla grupy dziewięciu specjalistów pracujących w zatrudniającym ponad trzy tysiące osób przedsiębiorstwie działającym w sektorach energetyki, sieci przesyłowych i transportu w Polsce Północnej. Specjaliści byli obserwowani pod kątem zachowań przejawianych podczas rozgrywki, zostali też poproszeni o wy-

* Adres do korespondencji: Marek Kalinowski, Uniwersytet Gdański, Wydział Zarządzania, Zakład Zarządzania Personelem, ul. Armii Krajowej 101, 81-824 Sopot, e-mail:markalski@gmail.com. 
pełnienie formularza ankiety. Dzięki uczestnictwu w rozgrywce, uczestnicy badania mogli wyrobić sobie pogląd czym jest gra szkoleniowa. Jest to o tyle istotne, że rozumienie pojęcia „gra decyzyjna” nie jest jednolite. To zróżnicowanie wynika ze stosowania w praktyce szkoleń pracowniczych nazwy „gra” w odniesieniu do ćwiczeń, które grami nie są, lecz co najwyżej zadaniami o sformalizowanym systemie oceny realizowanymi w klimacie rywalizacji. Drugą przyczyną błędnego pojmowania pojęcia „gra decyzyjna" jest indywidualne, niekiedy intuicyjne podejście do tworzenia tego typu narzędzi szkoleniowych przez pracowników, którzy w organizacji odpowiadają za przygotowanie i realizację szkoleń. W konsekwencji zdarza się, że za grę decyzyjną są uznawane gry oparte na idei quizu, np. polegające na przemieszczaniu pionka po planszy i odpowiadaniu na pytania zapisane na losowanych kartkach. W związku ze stosowaniem między innymi takich metod szkoleniowych w badanej organizacji, autor opracowania uznał za właściwe umożliwienie badanej grupie wzięcia udziału w rozgrywce spełniającej kryteria gry decyzyjnej, aby uzyskać kompetentne opinie na temat tego typu narzędzia. W niniejszym opracowaniu przedstawiono istotę gry decyzyjnej, opisano zastosowaną w badaniu grę decyzyjną i przedstawiono wyniki obserwacji uczestników sesji oraz zaprezentowano wnioski z badania ankietowego.

\section{ISTOTA GRY DECYZYJNEJ}

W gospodarce opartej na wiedzy bardzo istotną rolę w kreowaniu wartości dodanej pełnią zasoby intelektualne pracowników. Rozwiązania umożliwiające efektywne kształtowanie struktury kompetencji organizacji stanowią obszar zainteresowania zarówno praktyków zarządzania, jak i badaczy. Kluczową płaszczyzną rozwoju wiedzy, umiejętności i postaw społecznych pracowników są szkolenia. Narzędzia i zasady ich realizacji należy oceniać przede wszystkim w kontekście zmieniających się uwarunkowań społeczno-technologicznych: rosnących oczekiwań klientów, ewoluującego stylu życia i pracy oraz poszerzającego się instrumentarium informatycznego. Oczekiwania klientów przekładają się na coraz wyższe wymagania stawiane zasobom ludzkim organizacji odpowiedzialnym za rozpoznawanie tych potrzeb i ustalanie optymalnego sposobu ich zaspokojenia. Duże tempo realizacji zadań zarówno w pracy, jak w życiu prywatnym oraz funkcjonowanie na rynku pracy przedstawicieli „pokolenia Y”, charakteryzującego się m.in. nastawieniem na dużą ilość bodźców i na zmienność 
otoczenia, determinuje konieczność dbałości o optymalizację metod, czasu i miejsca szkolenia. Obecnie mówi się o „cyfrowej społeczności”, dla której zupełnie naturalne jest funkcjonowanie w wirtualnej rzeczywistości wykreowanej np. przez system informatyczny [Wach-Kąkolewicz, 2014, s. 19]. Nowoczesne rozwiązania IT z jednej strony poszerzają wachlarz rozwiązań możliwych do zastosowania, ale z drugiej strony wpływają na wzrost oczekiwań pracowników odnośnie doboru metod szkolenia.

Gry szkoleniowe są relatywnie nową metodą kształtowania kompetencji wpasowującą się w specyfikę współczesnych oczekiwań społecznych. Od gry rozrywkowej różni ją cel - dydaktyka [Michael, Chen, 2005, s. 19], co jest podkreślane poprzez coraz powszechniejsze stosowanie nazwy serious games [Mayer, Bekebrede, Harteveld, Warmelink, Zhou, Ruijven, Lo, Kortmann, Wenzler, 2014, s. 502]. Stanowią one interaktywne, dynamiczne odwzorowanie rzeczywistości, jego uczestnicy dążą do osiągnięcia sparametryzowanych celów. Interaktywność gry polega na umożliwieniu uczestnikowi szkolenia ingerowania w układ parametrów symulowanych w grze poprzez podejmowanie decyzji i działań w ramach określonych zasadami gry [Kalinowski, 2013 s. 119]. Dynamizm oznacza zmienność czynników gry, w tym parametrów ilościowych, generowaną aktywnością graczy lub działaniem czynników zaimplementowanych $\mathrm{w}$ mechanizmie gry (np. wydarzenia losowe, sterowane algorytmem zmiany stanu lub kosztów pozyskania potrzebnych zasobów, wprowadzanie kolejnych zadań do realizacji itp.). Gra odwzorowuje te zjawiska i obiekty realnego świata, których dotyczy szkolenie [Arnab, Lim, Carvalho, Bellotti, Freitas, Louchart, Suttie, Berta, Gloria, 2015, s. 395], choć sama fabuła może być osadzona w fikcyjnym świecie [Harteveld, 2012, s. 86], a nawet mieć abstrakcyjny charakter. Tym samym metoda gry szkoleniowej poprzez zapewnienie bezpiecznego środowiska, w którym aktywność uczestnika nie wiąże się z rzeczywistymi konsekwencjami [Akl, Kairouz, Sackett, Erdley, Mustafa, Fiander, Gabriel, Schünemann, 2013, s. 4], pozwala zarówno na kształtowanie kompetencji poprzez doświadczanie, jak i na ocenę tych kompetencji w oparciu o kryteria behawioralne i efektywnościowe. Mierzalność stopnia realizacji celów gry umożliwia obiektywną ocenę jakości decyzji i działań podejmowanych przez uczestników podczas rozgrywki [Kalinowski, Dobrowolska, 2014, s. 96.], nie tylko osobie prowadzącej szkolenie, ale także uczestnikowi szkolenia, dla którego możliwość skonfrontowania wyniku gry z wynikami rozgrywek wcześniejszych lub z wynikami innych uczestników szkolenia, stanowi silny bodziec do pełnego zaangażowania się w udział w grze. 
Gry decyzyjne są uniwersalnym narzędziem. Wykorzystuje się je w związku z działaniami pracodawców, takimi jak: szkolenia, adaptacja pracownicza, badanie kompetencji i integracja pracowników, ale także są stosowane w ramach systemu edukacji [Kajrunajtys, Szarecki, 2013, s. 158] oraz w doradztwie zawodowym [http://www.inwestycjawkadry. info.pl/szkolenie-doradztwo_zawodowe,sz,167732.html].

\section{OPIS GRY DECYZYJNEJ ZASTOSOWANEJ W BADANIU}

Gra wykorzystana do zbadania percepcji gier decyzyjnych przez specjalistów z obszaru HR jest planszową grą szkoleniową odnoszącą się do problematyki zarządzania zasobami ludzkimi. Uczestnicy rozgrywki wcielają się w przedsiębiorców wytwarzających i sprzedających produkty, a ich celem jest maksymalizacja zysku. Wartość produkcji wytwarzanej w wirtualnym przedsiębiorstwie jest wypadkową czterech kompetencji zatrudnianych pracowników. Decyzje uczestników gry odnoszą się do planowania zasobów ludzkich oraz zarządzania kosztami pracy, zatrudniania, szkolenia, przemieszczania, wynagradzania i zwalniania pracowników oraz określania realizowanych przez nich zadań. Planowanie zasobów ludzkich dotyczy w głównej mierze ustalania sposobów zapewnienia prowadzonej organizacji struktury kompetencji umożliwiającej optymalizowanie celów produkcyjnych. Zarządzanie kosztami pracy dotyczy kształtowania struktury płac i planowania wydatków szkoleniowych, a także kosztów związanych $\mathrm{z}$ employer branding. W grze zaimplementowano mechanizmy rywalizacji i kooperacji. Rywalizacja pomiędzy uczestnikami rozgrywki jest naturalną konsekwencją rankingu tworzonego w oparciu o kwoty zarobionych przez nich pieniędzy, ale także dotyczy konkurowania o wykwalifikowanych pracowników. Kooperacja z kolei polega na możliwości delegowania pracowników ze swojej firmy do firmy innego uczestnika. Na skutek decyzji podejmowanych przez graczy zatrudniani przez nich wirtualni pracownicy przejawiają satysfakcję lub demotywację, które wraz z wartością działań employer brandingowych firmy, wpływają na efektywność pracowników oraz na ich przywiązanie do pracodawcy.

Do ważniejszych fizycznych elementów gry zastosowanej w badaniu należą: plansza główna przedstawiająca aktualny i prognozowany rynek pracy, plansze graczy, których najistotniejszym elementem jest tabela taryfikacyjna z ruchomymi kategoriami zaszeregowania oraz karty symbolizujące pracowników, na których za pomocą różnokolorowych żetonów są 
oznaczane ich kompetencje oraz poziom satysfakcji i demotywacji. Każdy z uczestników otrzymał skróconą instrukcję gry zawierającą najważniejsze zasady oraz ilustrujące je przykłady. Czas rozgrywki przewidziany jest na 45-60 minut, podczas których przeprowadza się sześć tur składających się $\mathrm{z}$ sześciu faz.

\section{WNIOSKI PŁYNĄCE Z OBSERWACJI SESJI GRY DECYZYJNEJ}

Sesja trwała półtorej godziny, przy czym jej pierwsza połowa została poświęcona na wyjaśnienie zasad gry oraz na rozgrywkę testową, a druga - na rozgrywkę właściwą, podczas której badacz udzielał odpowiedzi na pytania zadawane przez uczestników. Uczestnicy nie mieli możliwości wcześniejszego poznania gry, gdyż instrukcja nie została im wcześniej przekazana, a sama gra nie jest nigdzie opublikowana. Wnioski płynące $\mathrm{z}$ analizy przebiegu sesji i zachowań uczestników są następujące:

1. W trakcie prezentowania instrukcji wyraźnie ewoluuje podejście uczestników wobec gry. W przypadku większej części uczestników można było zaobserwować określony ciąg kolejno następujących po sobie postaw: zaintrygowanie, ciekawość, świadomość, że nie wszystkie informacje udało im się zapamiętać lub zrozumieć, sceptycyzm, podjęcie działań ukierunkowanych na uzupełnienie informacji niezbędnych do udziału w rozgrywce i zaangażowanie intelektualne w rozgrywkę. Można też wyodrębnić dwie mniejsze grupy uczestników: pierwszą, która pomija fazę sceptycyzmu, co może świadczyć o większej łatwości przyswajania przekazywanych informacji oraz o nastawieniu na realizację celu i drugą grupę, u której sceptycyzm przeradza się w zniechęcenie. Zniechęcenie osoby biorącej udział w rozgrywce powoduje mentalną blokadę, a ta $\mathrm{z}$ kolei pogłębia dysonans pomiędzy zakresem posiadanych przez nią informacji niezbędnych do udziału w rozgrywce, a zakresem informacji posiadanych przez innych uczestników sesji. Z tej obserwacji płynie wniosek, że poziom trudności i złożoność gry powinna być dostosowana do możliwości percepcyjnych graczy, w przeciwnym wypadku zbyt liczny odsetek zniechęconych osób może ,zarazić” negatywnym nastawieniem pozostałych uczestników. Niektóre osoby od początku sesji okazują bierność ze względu na niechęć do gier lub z powodu zauważenia w zasadach gry rozwiązań, z którymi się nie zgadzają. 
W przypadku opisywanej sesji jedna z osób podważyła zastosowane w modelu uproszczenie polegające na możliwości zwolnienia pracownika z wirtualnej firmy bez ponoszenia jakichkolwiek konsekwencji. Takie osoby bardzo trudno zaangażować, gdyż następuje zamknięcie się na grę, co praktycznie uniemożliwia aktywne uczestnictwo w rozgrywce.

2. W przypadku niejasności co do zasad, uczestnicy preferowali zadawanie pytań prowadzącemu niż analizowanie dołączonej instrukcji. Mogło to wynikać z ich przekonania, że komunikat słowny może być bardziej zrozumiały lub $\mathrm{z}$ chęci uniknięcia wysiłku wiążącego się z analizą wydrukowanego tekstu. To drugie wyjaśnienie wydaje się bardziej prawdopodobne, gdyż samo wskazanie odpowiedniego fragmentu instrukcji zazwyczaj okazywało się wystarczające, by uczestnik uznał zgłoszony problem za rozwiązany.

3. Mimo wyraźnej sugestii prowadzącego spotkanie, że uczestnicy powinni dążyć do indywidualnego zwycięstwa, byli oni raczej nastawieni na wspólne omawianie zasad i doradzanie sobie wzajemnie optymalnych decyzji. Zauważalne było, że osoby, którym udało się szybciej zrozumieć poszczególne aspekty gry (zazwyczaj dzięki korzystaniu $\mathrm{z}$ wydruku instrukcji) z chęcią pomagały innym graczom, którzy mieli problem $\mathrm{z}$ ich opanowaniem. Ponadto wykazywano niechęć do wykorzystania pełnej gamy działań prowadzących do wygranej np. konkurowania o wykwalifikowanych pracowników zatrudnionych w firmach innych uczestników. Może to wynikać z indywidualnej hierarchizacji celów - gracze za priorytetowy problem uznali opanowanie zasad gry, natomiast zwycięstwo w rozgrywce znalazło się na dalszym planie. Dodatkowo poczucie solidarności wynikające $\mathrm{z}$ faktu zatrudnienia $\mathrm{w}$ tej samej organizacji mogło być silniejsze od presji osoby z zewnątrz zachęcającej do agresywnych działań przewidzianych w instrukcji. Podczas sesji gry szkoleniowej realizowanej z grupami studentów podczas zajęć dydaktycznych, można było zauważyć, że początkowe nastawienie na „pokonanie wspólnego wroga" w postaci wykładowcy narzucającego trudne zadanie, po oswojeniu się $\mathrm{z}$ regułami gry ewoluowało $\mathrm{w}$ kierunku zwiększenia skuteczności działań poprzez przejmowanie pracowników innych graczy.

4. Zaangażowanie osoby prowadzącej sesję w udzielanie wszelkich informacji dotyczących zasad gry zostało odebrane przez część uczestników jako zachęta do zadawania pytań odnośnie analizy struktury 
kompetencji w wirtualnej firmie i sposobów optymalizacji strategii działania, a więc w obszarach, w których uczestnicy mieli samodzielnie podejmować decyzje, ćwicząc swoje kompetencje. Prowadzący szkolenie powinien więc mieć świadomość zakresu, w którym jest uprawniony do udzielania informacji uczestnikom, w przeciwnym wypadku gra szkoleniowa przestanie służyć realizacji stawianych jej celów.

5. Uczestnicy sesji bardzo chętnie opłacali fakultatywne wydatki z kategorii employer branding mimo że generowały one wysokie koszty, ale nie przekładały się na adekwatne korzyści. Mogą być dwa powody takiej sytuacji. Pierwszy z nich to przeświadczenie, że jeśli gra oferuje określoną akcję w wyeksponowany sposób (finansowaniu employer branding w każdej turze jest poświęcony jeden z sześciu etapów każdej tury), to należy z tej możliwości skorzystać. Drugie wyjaśnienie to projekcja rzeczywistych wartości i przeświadczeń uczestników na decyzje podejmowane w grze. Specjaliści z obszaru HR są słusznie przekonani o dużej wadze tego typu inwestycji i niejako automatycznie decydują się na związane z nimi wydatki nie odnosząc ich do mechaniki gry. Podobne zachowania autor miał możliwość zaobserwować podczas rozgrywki gry firmy MindLab „Twój czas” - mechanika tej gry zakłada rezygnację z realizacji nisko punktowanych zadań zlecanych przez wirtualnego przełożonego, tymczasem uczestnikom szkolenia zatrudnionym w organizacjach wymagających dużej sumienności trudno było takie założenie zaakceptować.

6. Po przyswojeniu informacji potrzebnych do samodzielnego udziału w rozgrywce, w przypadku kilku uczestników można było zaobserwować wysoki poziom zaangażowania przejawiający się spontanicznym okazywaniem emocji - śmiechami, a nawet wypowiedziami stanowiącymi zdecydowany przejaw niezadowolenia. Te zachowania nie dotyczyły m.in. tych osób, które wcześniej ujawniły swój sceptycyzm.

\section{OPINIE UCZESTNIKÓW SESJI NA TEMAT ZASADNOŚCI STOSOWANIA GIER DECYZYJNYCH}

Formularz ankiety składa się z ośmiu pytań dotyczących: znajomości gier planszowych i szkoleniowych oraz stosunku do tego typu produktów, prak- 
tyki w zakresie stosowania gier decyzyjnych oraz opinii na temat przydatności gier szkoleniowych w szkoleniu pracowników. Bezpośrednio po zakończeniu rozgrywki ankieta została rozdana wszystkim dziewięciu uczestnikom. Wśród nich było osiem kobiet i jeden mężczyzna. Wszyscy zajmują stanowiska pracy merytorycznie związane z obszarem zarządzania zasobami ludzkimi, przy czym dwie osoby zajmują stanowiska menedżerskie. Doświadczenie zawodowe respondentów mieści się w przedziale od siedmiu do piętnastu lat. Wszyscy uczestnicy mają wykształcenie wyższe.

Na pytanie o znajomość komercyjnych gier planszowych jedynie trzy osoby nie wskazały żadnych tytułów, pozostałe wyszczególniły od jednego do czterech tytułów. Tylko jedna osoba wymieniła tytuły kilku gier mających cechy gier decyzyjnych: Osadnicy z Catanu, Carcassonne i Splendor. Z innych, bardziej interesujących wskazań, można wymienić Monopol ( 2 os.), szachy ( 1 os.), poker ( 1 os.). Nikt nie wskazał produktów adresowanych do zaawansowanych graczy.

Na pytanie o postrzeganie gier planszowych dominowała odpowiedź, że „ćwiczą intelekt” ( 7 os.) i rozwijają kontakty interpersonalne (4 os.). Jedynie trzy osoby przyznały, że lubią gry. Na pytanie dotyczące znanych uczestnikowi gier szkoleniowych tylko jedna osoba wymieniła trzy tytuły, natomiast pozostałe osoby nie wskazały takich gier. Jednak na pytanie dotyczące stosowania gier szkoleniowych cztery osoby zadeklarowały, że stosują je jako uzupełnienie szkolenia, a jedna z osób dodatkowo zaznaczyła odpowiedź „stosuję jako podstawę szkolenia”.

Ankietowani zdecydowanie pozytywnie ocenili gry decyzyjne jako narzędzie kształtowania kompetencji. Na pytanie o jego skuteczność udzielono siedmiu twierdzących odpowiedzi (3, ,zdecydowanie tak” i 4 ,,raczej tak”). Dwie osoby zaznaczyły opcję „raczej nie”, przy czym jedna z nich podkreśliła walor ewaluacyjny gier.

Uczestnicy badania zostali zapytani o zalety, jakie ich zdaniem mogłyby mieć dobrze zaprojektowane gry decyzyjne. Wśród odpowiedzi wskazywano na możliwość zobrazowania pracownikom określonych elementów rzeczywistości, w tym relacji i zależności, ułatwienie zapamiętania tematyki szkolenia dzięki towarzyszącym rozgrywce emocjom, pobudzenie myślenia strategicznego i wyobraźni, możliwość dostosowania do nowego środowiska, a także ich walor rekreacyjny.

Wskazano przede wszystkim dwie słabe strony gier decyzyjnych: pierwsza $z$ nich to odwzorowywanie realnego świata, w tym konsekwencji podejmowanych decyzji w zbyt uproszczony sposób, natomiast druga to konieczność poświęcenia zbyt dużej ilości czasu na opanowanie zasad. 
Ostatnie pytanie dotyczyło porównania oceny skuteczności kształtowania za pomocą gier decyzyjnych ośmiu wybranych kompetencji i postaw w porównaniu do innych metod szkoleniowych. Najwyżej (w przedziale 4,51-5) oceniono rywalizację i umiejętność podejmowania decyzji. Nieco niżej (4,01-4,5) oceniono myślenie analityczne, myślenie perspektywiczne i myślenie ekonomiczne. W granicach 3,51-4,0 uplasowały się umiejętności negocjacyjne i świadomość występowania określonych zjawisk. Najniżej - w przedziale 3,01-3,5 - została zakwalifikowana kooperacja.

\section{PODSUMOWANIE}

Opinie badanych specjalistów HR na temat przydatności gier decyzyjnych są pozytywne. Ze względu na stosunkowo niedużą znajomość przez nich tego typu narzędzi, ideę gry szkoleniowej oceniali przez pryzmat przykładowego produktu posiadającego cechy gry decyzyjnej, nie będącego w sprzedaży. Wskazano, że gry decyzyjne mogą być wykorzystywane jako uzupełnienie szkolenia. Według respondentów mogą one stanowić efektywny sposób kształtowania pewnych kompetencji i postaw, głównie związanych z rywalizacją i podejmowaniem decyzji. Obserwacja procesu przyswajania zasad gry oraz przebiegu rozgrywki pozwoliły wyróżnić etapy, przez które przechodzi uczestnik gry szkoleniowej, a także zidentyfikować pewne charakterystyczne postawy, np.: przenoszenie na grę doświadczeń i przekonań gracza, traktowanie przyswajania zasad gry jako wyzwania wymagającego pracy zespołowej czy tendencja do dużego zaangażowania emocjonalnego.

\section{LITERATURA}

Akl E.A., Kairouz V.F., Sackett K.M.,. Erdley W.S, Mustafa R.A., Fiander M., Gabriel C., Schünemann H., Educational games for health professionals (Review), The Cochrane Library 2013, Issue 3, Wiley.

Arnab S., Lim T., Carvalho M.B.,. Bellotti F., Freitas S., Louchart S., Suttie N., Berta R., Gloria A., Mapping learning and game mechanics for serious games analysis, British Journal of Educational Technology 2015, Vol. 46, No 2.

Harteveld C., Making Sense of Virtual Risks, IOS Press, Amsterdam 2012, NLD.

http://www.inwestycjawkadry.info.pl/szkolenie-doradztwo_zawodowe,sz,167732. html [dostęp: 08.06.2015]. 
Kajrunajtys D., Szarecki M., Gra edukacyjna jako narzędzie ksztattowania kompetencji społecznych na przykładzie WSEI, Wyższa Szkoła Ekonomii i Informatyki w Krakowie Kraków 2013, Zeszyt 9.

Kalinowski M., Gry decyzyjne jako nowoczesne narzędzie rozwoju kompetencji menedżerskich, w: Uwarunkowania sukcesu organizacji, red. Czubasiewicz H., Mokwa Z., Walentynowicz P. Fundacja Rozwoju Uniwersytetu Gdańskiego, Gdańsk 2013.

Kalinowski M., Dobrowolska E., Strategiczne gry szkoleniowe jako narzędzie ksztaltowania kompetencji menedżerskich, w: Sukces w zarzadzaniu kapitałem ludzkim - podejścia, metody, narzędzia, red. Stor M., Fornalczyk A., Prace naukowe Uniwersytetu Ekonomicznego we Wrocławiu nr 350, Wydawnictwo Uniwersytetu Ekonomicznego we Wrocławiu, Wrocław 2014.

Mayer I., Bekebrede G., Harteveld C., Warmelink H., Zhou Q., Ruijven T., Lo J., Kortmann R., Wenzler I., The research and evaluation of serious games: Toward a comprehensive methodology, British Journal of Educational Technology 2014, Vol 45, No 3.

Michael D., Chen S., Serious Games: Games That Educate, Train, and Inform, Thomson, Boston, USA 2005.

Wach-Kąkolewicz A., Learning and teaching with electronic games as an educational method, w: The Strategic Management Virtual Game Method in Business Education, red. Gaweł A., Pietrzykowski M., Ius At Tax, Warszawa 2014.

\title{
USE OF SERIOUS GAMES IN HUMAN RESOURCE DEVELOPMENT
}

\begin{abstract}
The aim of the study is to find out the opinions of HR professionals on the usefulness of decision games. Due to respondents little knowledge of this type of training tools, before the survey was conducted, the decision game was played. The respondents claimed that decision games can be used as a supplement to a training process. According to respondents, such games can be an effective way of training certain skills and shaping attitudes, mainly related to the competition and decision-making. Observing the process of learning the rules of the game and the gameplay the researcher has found stages through which the players proceed, as well as has identified some characteristic posture, for example: transferring individual experiences and beliefs to the game, treating learning rules of the game as a challenge that requires teamwork and tendency to strong emotional commitment.
\end{abstract}

Keywords: serious games; training; development. 